\title{
EPITAF SA ZAGOVOROM DOBROM PASTIRU \\ Prijedlog za sarkofag trogirskog biskupa Ivana
}

\section{Vanja Kovačić}

\author{
V. Kovačić \\ Ministarstvo kulture Republike Hrvatske \\ Konzervatorski odjel - Split \\ Porinova 2 \\ HR-21000 Split \\ vanjagisela@gmail.com
}

\begin{abstract}
This article discusses the find of the forecourt of the medieval hexafoil St Mary's church within the perimeter of the Renaissance Church of St Sebastian in the main square in Trogir. A sarcophagus found earlier in the centre of St Mary's indicated that it had a sepulchral and memorial importance, while the early medieval sarcophagi in the forecourt had the features of privileged interments. The epitaph with a prayer for intercession to the Good Shepherd was compiled from fragments of Psalm 22:1 and St John's Gospel, 10:14, 27-28. Information from the Life of St John of Trogir and the bishop's prayer at the hour of his death are compared with the wording on the sarcophagus and related to the re-interment of Bishop John in the Cathedral of St Lawrence in 1150.
\end{abstract}

Key words: Trogir, Church of St Mary, hexafoil, Church of St Sebastian, forecourt, sarcophagi, epitaph, St John of Trogir

Tijekom rada na bogatoj ranokršćanskoj i srednjovjekovnoj baštini Dalmacije, profesor Igor Fisković je, promišljajući reutilizaciju spolija s križevima, napisao: „Fragmenti tih izrađevina su u srednjem vijeku ugrađivani na portalima i u oltarima novih svetišta te imaju simbolički jasnu namjenu, odnosno određene ideološke intencije i duhovne konotacije bez obzira jesu li dostupni pogledu ljudi ili skriveni kao prave relikvije". ${ }^{1}$ Potvrda o simboličkom smislu čina ugradnje spolija iznesena je i u ovom radu što ga s radošću i poštovanjem posvećujem Profesoru o njegovoj obljetnici.

Istraživači srednjovjekovnog Trogira su u proučavanju slike grada posebnu pozornost obraćali položaju antičkih natpisa i križeva ugrađenima nad ulazima i na uglovima medijevalnih kuća čija je nakana bila mir ukućanima i zaštita od zla. Spoliji s križevima ugrađivani su u novi kontekst kao posvetno kamenje, a sarkofazi priklesavani i kristijanizirani.

U ovom prilogu posebno ćemo se osvrnuti na natpis pronađen prilikom istraživanja crkve sv. Sebastijana u kontekstu srednjovjekovnog sloja koji je prethodio njezinoj renesansnoj pregradnji. Prilikom Firentinčevog preoblikovanja glavnog trogirskog trga, južna je strana artikulirana na nov način pa je nekadašnje predvorje šesterolisne crkve sv. Marije, kao i gradska loža, postalo element šire urbanističke regulacije. ${ }^{2}$ Prema arhivskom gradivu, kod crkve sv. Marije i u njezinu predvorju bila je potvrđena

\footnotetext{
${ }^{1}$ I. FISKOVIĆ, „Ranokršćanski križevi u srednjovjekovnim crkvama Dalmacije“, in: Opuscula archeologica 23-24, Zagreb, 1999.-2000., 237-250; Idem, „Solinski tip ranokršćanskih sarkofaga“, in: Arheološki radovi i rasprave 12 (ARR), Zagreb, 1996., 117-140.

${ }^{2}$ C. FISKOVIĆ, „Firentinčev Sebastijan u Trogiru”, in: Zbornik za umetnostno zgodovino (Zbornik F. Stelea), V-VI, Ljubljana, 1959., 368-375; R. BUŽANČIĆ, Nikola Ivanov Firentinac i trogirska renovatio urbis, Split, 2012.,117-128.
} 


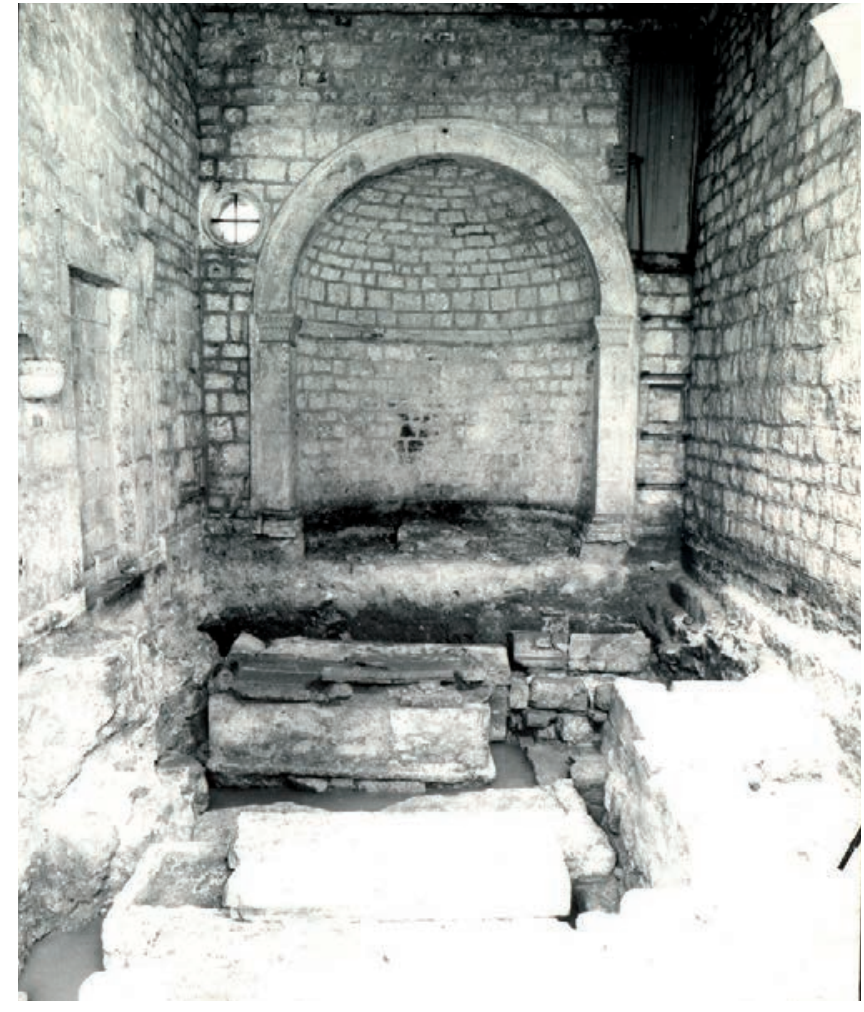

Sl. 1. Unutrašnjost crkve sv. Sebastijana s pronadenim sarkofazima u predvorju crkve sv. Marije

Fig. 1. The interior of the Church of St Sebastian with the sarcophagi found in the forecourt of the Church of St Mary.

vjerodostojnost raznih ugovora i sporazuma, a iskopavanjima je utvrđena sepulkralna namjena tog prostora neposredno pred ulazom u crkvu. Gradnjom crkve nad ranosrednjovjekovnim trijemom, posvećene sv. Sebastijanu, tu se u 15. stoljeću koncentrira središte pobožnosti svecu-zaštitniku kao kolektivni zavjet cijele zajednice protiv kužnih bolesti.

Tijekom uređenja pločnika crkve sv. Sebastijana, pronađeni su zidovi nekadašnjeg trijema crkve sv. Marije koji je bio nešto širi od zapadne konhe šesterolista i znatno manjeg raspona $u$ odnosu na renesansnu crkvu. ${ }^{3} U$ unutrašnjosti Sv. Sebastijana je na istočnom zidu bila vidliiva lučno zasvedena plitka niša, a sondiranjem zida otkriven je spoj zapadne konhe sa sljedećom prema sjeveru. Njezin vanjski plašt s ožbukanim lezenama sačuvan je u punoj visini, a sporadično se uočavaju sitne gotičke rukopisne bilješke. Prilikom konzervatorskih istraživanja ponutrice renesansne crkve, ustanovljeni su izvorni ritam i veličina lezena na vanjštini sjeverozapadne konhe budući da su ostali perimetralni zidovi šesterolista $\mathrm{u}$ dvorištu pronađeni ispod razine njihova podanka. Ulaz u trijem crkve sv. Marije bio je asimetrično postavljen na sjevernoj strani, što je, po svoj prilici, rezultat postojeće urbanističke matrice. Prilikom arheoloških istraživanja predvorja trogirske rotunde i njezina neposrednog okoliša, u prizemlju i dvorištu župnoga dvora izdvojena su dva arheološka sloja, arhitektonski jasno definirana, od kojih stariji pripada kasnohelenističkoj stambenoj arhitekturi. ${ }^{4}$ Nedvojbeno je da su šesterolisna crkva sv. Marije i crkveno predvorje sepulkralne namjene neposredno superponirani antičkoj arhitekturi. Paralelno sa zapadnim zidom renesansne crkve sv. Sebastijana odnosno gradske lože bio je helenistički zid koji je mogao pripadati lateralnom kardu. ${ }^{5}$

Predvorje crkve sv. Marije unutar prostora crkve sv. Sebastijana bilo je podijeljeno na dvije zidane grobne komore s ukopima u sarkofazima, dok su u međuprostorima bili zidani grobovi i grobovi s kamenim obložnicama (sl. 1). Sarkofazi su temeljeni na kasnoantičkim pilastrima i nadvatnicima sa

\footnotetext{
${ }^{3}$ Obnovu crkve započeo je Regionalni zavod za zaštitu spomenika kulture iz Splita, a arheološka i konzervatorska istraživanja tijekom ožujka i travnja 1988. godine vodila je autorica ovih redaka s kolegom R. Bužančićem. Godine 1997. postaje memorijalna kapela u spomen na branitelje s trogirskog područja poginule tijekom Domovinskog rata, a ponovno ju je posvetio tadašnji splitsko-makarski nadbiskup Ante Jurić.

${ }^{4}$ V. KOVAČIĆ, „Nuove scoperte nella Tragurion ellenistica“, in: Grčki utjecaj na istočnoj obali Jadrana: Zbornik radova sa znanstvenog skupa održanog 24. do 26. rujna 1998. godine u Splitu, Greek Influence along the East Adriatic Coast: Proceedings of the International Conference Held in Split from September 24th to 26th 1998; N. CAMBI, S. ČAČE, B. KIRIGIN (ed.), Književni krug Split, Split, 2002., 378-380.

${ }^{5}$ Novija arheološka istraživanja poduzeta su prilikom uređenja dvorišta i prizemlja župnoga dvora 1989. i 2002. godine. S obzirom na dokument iz ranog 8. stoljeća i suprotstavljena domišljanja koje je izazvao u znanstvenim krugovima, neophodno bi bilo poduzeti revizijska istraživanja u unutrašnjosti crkve sv. Marije, što su već ranije upozorili M. Jurković i Ž. Rapanić. Ona će zasigurno dopuniti dosadašnja saznanja o nastanku trogirske heksagonalne građevine i suvremenim metodama utvrditi vertikalnu stratigrafiju na ovom iznimno važnom dijelu urbane strukture Trogira.
} 


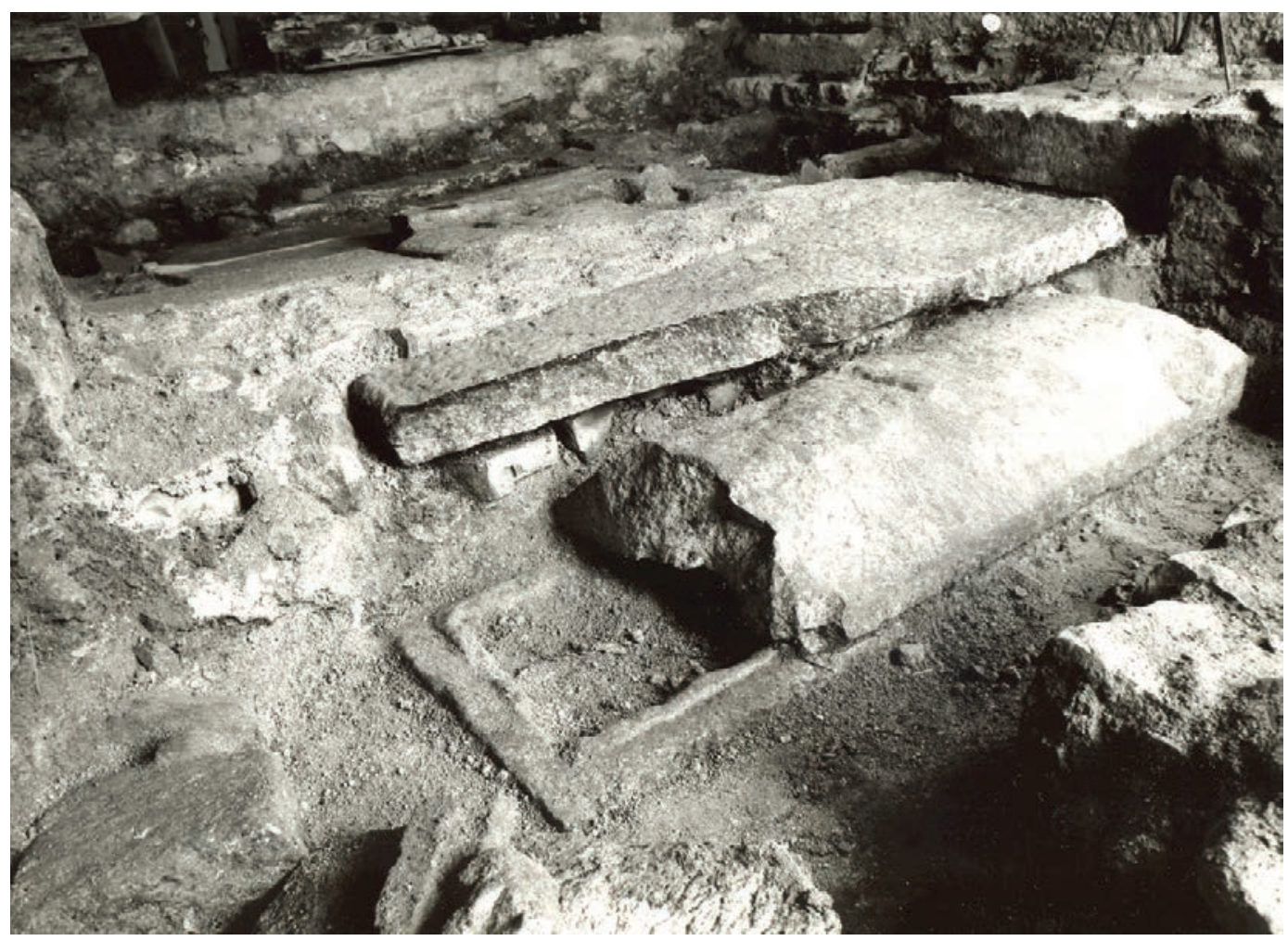

Sl. 2. Ploča s epitafom ugradena u pločnik nad sarkofagom

Fig. 2. Slab with epitaph incorporated into the paving over the sarcophagus

znakom križa, a teren je poravnat fragmentima poganskog sarkofaga s manjim rustičnim figurama. U srednjem vijeku prestaje masovna produkcija sarkofaga i koriste se antički sarkofazi s postojećih poganskih groblja. Ispod pločnika trijema bila su ukopana tri sarkofaga s poklopcima, te pronađeni dijelovi jednog antičkog i jednog srednjovjekovnog sarkofaga. U sjevernoj komori bio je samo jedan sarkofag s "tabulom ansatom” i nadgrobnim natpisom koji spominje neprežaljenu pokojnicu i suprugu. Na rubu dvostrešnog poklopca s priklesanim akroterijima urezano je $D$ (iis) $M$ (anibus). Sarkofag je bio više puta otvaran o čemu svjedoči veći broj pokojnika i priloženi spalatini, a nad poklopcem je u pločniku bila ugrađena kamena ploča, zapravo prednja strana ranoromaničkog sarkofaga s epitafom koji ćemo kasnije razmatrati (sl. 2).

U drugoj grobnoj komori otkrivena su dva sarkofaga: sanduk bez ukrasa, pokriven plitkim dvoslivnim poklopcem s reljefnim križem zakrivljenih krajeva poput sidrastih križeva (crux ancorata). Po ukrasu poklopca sličan je onom na sarkofagu priora Petra s rašljasto oblikovanim završecima krakova, kojem nedostaje središnja antena. Toj tipologiji pripada dio poklopca pronađen 1894. godine u Trogiru (danas u Arheološkom muzeju u Splitu) na kojem su plosnati krakovi ispunjeni pletenicom s krajevima što završavaju poput volute. Južno je bio najveći sarkofag izvorno s natpisom u tabuli ansati koja je gotovo potpuno radirana. U sredini je izrađen motiv križa pod arkadom kao simbol Uskrsnuća, a prikaz je okrenut prema oltaru. Glatki plosnati križ s lagano proširenim krakovima natkriljen je lukom ukrašenim astragalom, koji nose stilizirani tordirani stupići. Na poklopcu s blago skošenim stranama je u plitkom reljefu izrađen latinski križ proširenih krakova, a na više su mjesta urezani križevi slični ranokršćanskima. Temeljen je na ranokršćanskim stupićima s križem, dok je dio nadvratnika s urezanim križem bio u zidu grobne komore. Svi su sarkofazi bili korišteni u 13. i 14. stoljeću, o čemu svjedoče nalazi mletačkih pikola i spalatina. ${ }^{6}$ Južno od velikog sarkofaga uz apsidu

${ }^{6}$ C. STOCKERT, „Le monete del Comune di Spalato", in: Prilog Bulletino di archeologia e storia dalmata, XL-XLI-XLII, 1917-1918-1919 (1922.), 1-35. 
sv. Sebastijana bio je zidani grob s prilogom jednog spalatina, a zapadno dječji grob i grob odraslog pokojnika od okomito postavljenih ploča. Između zidanog groba i velikog predromaničkog sarkofaga pronađen je srebrni pikolo dužda Pietra Gradeniga (1289. - 1311.).?

Prilikom istraživanja crkve sv. Marije, koje je proveo Urbanistički biro iz Splita od 1957. do 1959. godine pod vodstvom Tomislava Marasovića, u središtu šesterolisne crkve pronađen je kameni sarkofag u smjeru istok-zapad. ${ }^{8}$ Sarkofag je bio ukopan na način da je izvorno poklopac bio u razini prvog pločnika, a poslije je nadozidan po obodu zidom grube strukture i ožbukan u unutrašnjosti kada se pločnik izjednačava s kasnijim pločnikom crkve sv. Sebastijana.

Prema navodima istraživača crkve sv. Marije, središnji sarkofag je bio izrađen od bijelog vapnenca i klesarski obrađen na svim stranama (1,78 x 0,50 x 0,50 m). Kako autor ne donosi više podataka o ostacima natpisa ili reljefa na stijenkama sarkofaga niti o eventualnim tragovima radiranja i priklesavanja, zasigurno bi njegov poklopac bio dragocjen za rješenje ove enigme. Nije poznat status tog pokojnika u Trogiru, kojim je djelima zadobio položaj u središtu crkve ni čime je zaslužio štovanje drugih pokopanih u sarkofazima predvorja. Pomicanje razine u trijemu odgovara sloju pločnika s nalazom ranosrednjovjekovnog zabata koji je reljefnim licem okrenut prema dolje, a glatkim začeljem ugrađen u pločnik. ${ }^{9} \mathrm{Na}$ uglu zabata je prikaz motiva borbe ribe i polipa, što je personifikacija borbe Krista i Sotone za duše pokojnika, a u središtu kompozicije križ flankiraju golubice i rozete kao simboli Sunca i Mjeseca što je znak Kristova Uskrsnuća odnosno trijumfa nad smrću. Dio sačuvanog teksta jest formula zagovora upućena Bogorodici pa smo zabat, sagledavajući njegove ikonografske i epigrafske odlike, datirali u 9. stoljeće i pripisali izvornoj fazi crkve sv. Marije in platea.

Put spolija u ovoj maloj gradskoj sredini svakako je nepredvidiv. Oni se reutiliziraju, spašavaju i ugrađuju bez prepoznavanja njihova povijesnog značenja i stječu novi smisao. Ponekad su grupirani u novoj sakralnoj ili sepulkralnoj namjeni, a stele ugrađene nad kućnim vratima i prolazima štite od zlih duhova one koji tu obitavaju. Dijelovi sarkofaga s natpisima ugrađeni su visoko na katedrali kao i na zvoniku samostana sv. Petra.

U iznimne nalaze ubraja se fragment poklopca sarkofaga s reljefnim križem i natpisom koji je pronađen koncem 19. stoljeća u Trogiru u dvorištu kuće Slade kod crkve sv. Petra. ${ }^{10}$ Plitki dvostrešni poklopac karakterističan je za ranosrednjovjekovne sarkofage, u dužini sljemena proteže se hasta, a poprečni se krakovi spuštaju niz obje strehe sa završecima u obliku voluta. Unutrašnjost krakova ispunjena je dvoprutom pletenicom s okulusima. Paralelno sa središnjom antenom i na rubu poklopca, poprečni je krak kao na okovanom sanduku, što se pojavljuje na sarkofagu iz predvorja Sv. Marije i na poklopcu sarkofaga priora Petra u Splitu. Natpis na trogirskom fragmentu samo je dijelom sačuvan, ali epigrafske odlike i spomen imena bizantskog cara Konstantina vezuju ga za drugu polovicu 8. st., u vrijeme vladavine Konstantina V. (741. - 775.) ili Konstantina VI. (780. - 797.). Glavni natpis na plohi strehe i onaj na rubnjaku poklopca prema Karamanu nisu iz istog vremena, dok ih M. Ivanišević smatra dijelovima jedinstvenog natpisa pokojnog Pavla koji traži od klerika i laika da se mole za njegovu dušu. ${ }^{11}$

\footnotetext{
${ }^{7}$ Zadnji su kronološki podaci o ukopima u trijemu crkve sv. Marije u ranom 14. stoljeću. Nakon gradnje crkve sv. Sebastijana, na tom mjestu, zavjetne crkve Trogirana protiv kuge, nema tragova o novim ukopima.

${ }^{8}$ T. MARASOVIĆ, „Iskapanje ranosrednjovjekovne crkve sv. Marije u Trogiru“, in: Starohrvatska prosvjeta (SHP), 8-9, Zagreb, 1963., 87-91; Idem, Dalmatia praeromanica, 3. korpus arhitekture, Srednja Dalmacija, Sv. Marija na trgu, Split-Zagreb, 2011., 128-135.

${ }^{9}$ V. KOVAČIĆ, "Zabat s formulom zagovora iz Trogira“, in: Prilozi povijesti umjetnosti u Dalmaciji 35 (PPUD), Petriciolijev zbornik I, Split, 1995., 293-302.

${ }^{10} \mathrm{Lj}$. KARAMAN, Spomenici u Dalmaciji u doba hrvatske narodne dinastije i vlast Bizanta na istočnom Jadranu u to doba, Šišićev zbornik, Zagreb, 1929.,183-188. Trogirski načelnik Josip Slade poklonio ga je društvu „Bihać” te se danas čuva u Arheološkom muzeju u Splitu. Donosi ga i T. BURIĆ, „Predromanička skulptura u Trogiru“, SHP 12, Split, 1982., 140, 155.

${ }^{11}$ M. IVANIŠEVIĆ, „Trogir u povijesnim izvorima od 438. do 1097. godine“, in: Mogućnosti, God. XXVII, Split, listopad-studeni 1980., n. 10-11, 969.
} 


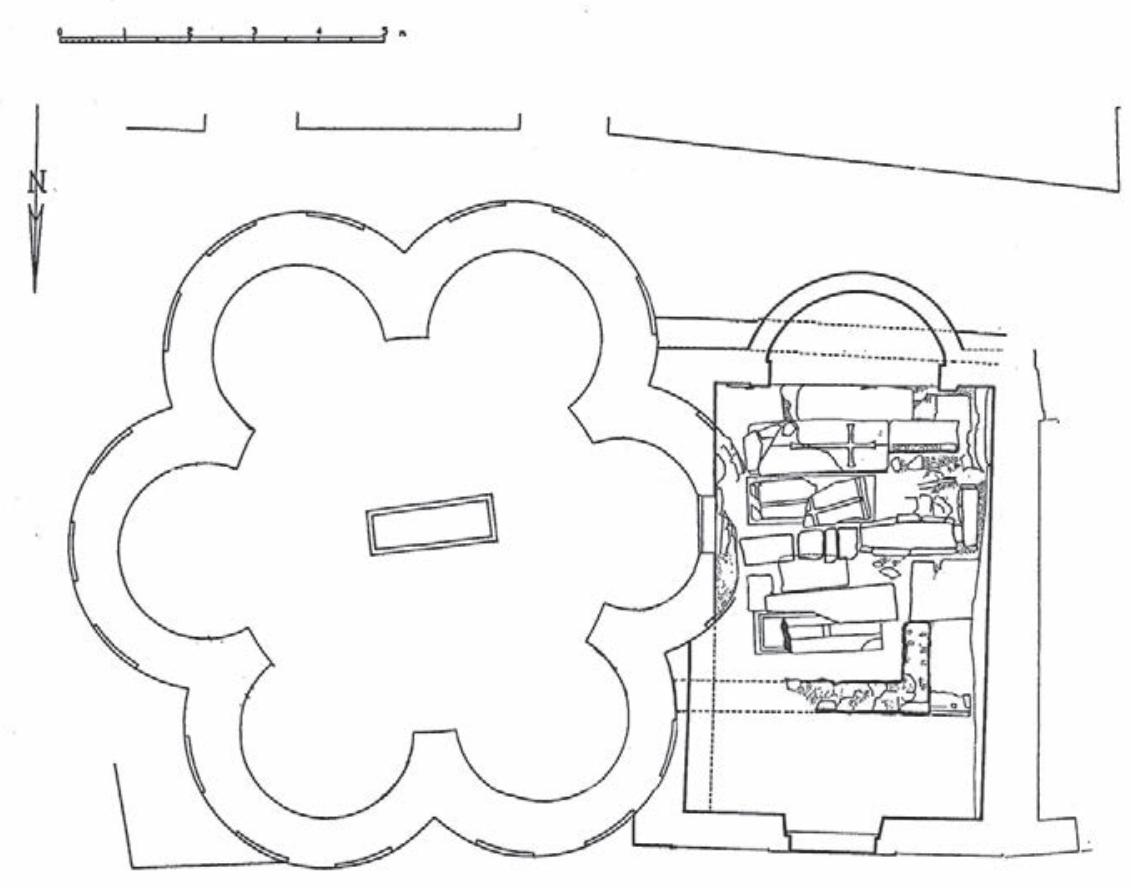

Sl. 3. Crkva sv. Marije s predvorjem i položajem sarkofaga (R. Bužančić)

Fig. 3. Church of St Mary with forecourt and position of the sarcophagus (R. Bužančić)

Oblik poklopca, njegov ukras i natpis stavljaju ga u kontekst ukopa u predvorju crkve sv. Marije. Usuđujemo se podsjetiti na sarkofag u središtu šesterolisne crkve kojemu je davno uklonjen poklopac, a stijenke nadograđene prilikom sekundarnih ukopa. Kao i sarkofazi u predvorju Sv. Marije, centralni je sarkofag bio ispod razine popločenja, a niski je pokrov omogućavao plitko ukopavanje arke, dok je nadgrobna oznaka vjerojatno bila u pločniku.

Razmatranja o razvoju heksakonhosa započeo je G. B. de Rossi, zaključivši da se u ranokršćanskoj arhitekturi Rima šesterostrani i šesterolisni mauzoleji adaptiraju u martirije s predvorjem. A. Grabar u temeljnoj raspravi o martiriju i kultu relikvija naglašava da autentični centralni martiriji kružnog ili poligonalnog tlocrta postaju svetišta nad svetim tijelom ili svetim mjestom na istaknutim kristološkim toposima Svete zemlje..$^{12}$ Pojava šesterolisnih crkvica s kupolom u hrvatskoj znanstvenoj javnosti donijela je niz raprava o njihovu porijeklu, tipologiji i kronologiji, ${ }^{13}$ a u manjoj mjeri i o njihovoj funkciji. ${ }^{14}$

${ }^{12}$ A. GRABAR, Martyrium, recherches sur le culte des reliques et l'art chrétien antique, vol. I, London, 1972., 148.

${ }^{13}$ S. GUNJAČA, „Starohrvatska crkva i kasnosrednjovjekovno groblje u Brnazima kod Sinja“, in: SHP 4, Split, 1955. 85-134; I. PETRICIOLI, „Neki preromanički spomenici Zadra i okolice u svjetlu najnovijih istraživanja“, in: Zbornik instituta za historijske nauke II, Zadar, 1956.-1957., 51-76; T. MARASOVIĆ, „Iskapanje ranosrednjovjekovne crkve sv. Marije u Trogiru“, op. cit. 87-91 (n. 8); S. GUNJAČA, „Srednjovjekovni Dolac kod Novigrada“, in: SHP 8-9, Split, 1963., 7-66; Idem, "Crkva Stomorica (S. Maria de Pusterla) u Zadru“, in: Diadora 4, Zadar, 1968., 247-269; J. MARASOVIĆ, T. MARASOVIĆ, M. MARASOVIĆ, Crkva sv. Trojice u Splitu, Split, 1971.; T. MARASOVIĆ, "Prilozi istraživanju starohrvatske arhitekture", in: Prilog morfološkoj klasifikaciji ranosrednjovjekovne arhitekture u Dalmaciji, Split-Zagreb, 1978., 5-129; V. DELONGA, „Starohrvatska crkva na "Mastirinama” u Kašiću kod Zadra“, in: SHP 18, Split, 1988., 39-89; P. Vežić, „O centralnim građevinama Zadra i Dalmacije u ranom srednjem vijeku“, in: Diadora 13, Zadar, 1991., 323; Ž. RAPANIĆ, „Sancta Maria de Platea u Trogiru. De ecclesiis datandis - dissertatio (1)“, in: SHP 25, Split, 1998., 43-62.

Topografski korpus šesterolisnih crkava s bibliografijom o njihovoj tipologiji, skulpturi i grobljima donosi T. MARASOVIĆ, Dalmatia praeromanica, 2. i 3. korpus arhitekture, Split-Zagreb, 2009. i 2011.

${ }^{14}$ M. JURKOVIĆ, „Predromanički šesterolisti Dalmacije - problemi funkcije“, in: PPUD 35, Split, 1995., 225-240; P. VEŽIĆ, „Dalmatinski šesterolisti - sličnosti i razlike“, in: Ars Adriatica 2, Zadar, 2012., 41-74. 


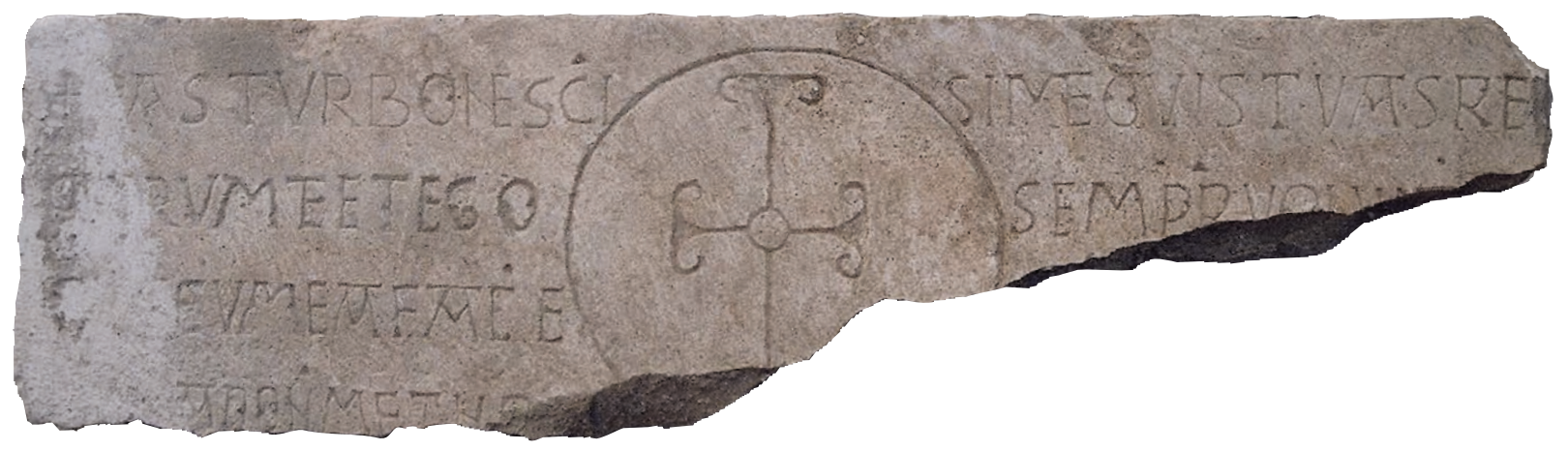

Sl. 4. Ranoromanički epitaf sa zagovorom Dobrom pastiru

Fig. 4. Early Romanesque epitaph with prayer of intercession to the Good Shepherd

Prvi je Igor Fisković na primjeru trogirske Sv. Marije sa sarkofagom u središtu građevine ukazao na mogućnost memorijalnog karaktera šesterolisnih crkvica u Dalmaciji. ${ }^{15}$ Ranosrednjovjekovni sarkofazi pod pločnikom trijema potvrđuju izuzetno štovanje groba u središtu Sv. Marije kada se samo istaknut sloj uglednika mogao pokapati u neposrednoj blizini memorije, uspostavljajući niz „privilegiranih ukopa" u sarkofazima i u nekoliko grobova u međuprostorima (sl. 3). ${ }^{16}$ Zabat s formulom zagovora Bogorodici bio je postavljen u građevini s izrazitim zagrobnim kultom, a karakter i brojnost nalaza u šesterolisnoj crkvi i njezinu predvorju potvrđuju izrazitu funeralno-memorijalnu funkciju.

Vraćamo se razmatranju dijela sarkofaga s natpisom koji je pronađen u pločniku sjeverne grobne komore, a nad sarkofagom s antičkim natpisom. Izvorno je ploča bila prednji dio sarkofaga od bituminoznog vapnenca s križem u krugu urezanom na sredini ploče i natpisom raspoređenim u četiri retka s obje strane križa. ${ }^{17}$ Urezana slova i križ bili su naglašeni crvenom bojom koja je ubrzo nestala nakon okretanja ploče. U središnjem krugu koji predstavlja stilizirani vijenac vitki je križ s čvorom u sjecištu i trokutasto proširenim i povijenim krajevima.

Radi se o reinterpretaciji ranokršćanskih sarkofaga bračke produkcije sa stiliziranim crux coronata, ${ }^{18}$ a u ranom srednjem vijeku su često reutilizirani te je urezan novi epitaf poput onoga priora Petra iz periptera splitske katedrale. Križ ima raščlanjene i povijene krajeve poput crux ancorata što je ranije

${ }^{15}$ I. FISKOVIĆ, „O grobnim spomenicima u srednjovjekovnoj Dalmaciji“, in: Dometi XVII/5, Rijeka, 1984., 45. I. Babić također iznosi pretpostavku da je rotunda mogla biti memorija odnosno grobna crkva nekoga lokalnog mučenika ili dostojanstvenika; usp. I. BABIC, Kulturno blago Trogira, Trogir, 1987., 113. Pokojnik je štovanje mogao zaslužiti posvećenim životom, svjedočenjem vjere i čudesnim ozdravljenjima u svojoj sredini. Gotovo je nevjerojatno da nije spomenut u crkvenim i povijesnim izvorima.

16 Ž. RAPANIĆ, op. cit., 58 (n. 13).

${ }^{17}$ Netom obrađen ili slomljen asfaltni kamen ima crnu boju, ali i svojstvo da tijekom vremena posvijetli. Brao se u antičkim kamenolomima kod Škripa na otoku Braču i često je korišten za opremanje prezbiterija ranokršćanskih crkava ili za izradu sarkofaga. I u ovom se slučaju vjerojatno radi o izradi srednjovjekovnog epitafa na antičkom sarkofagu. ${ }^{18}$ I. FISKOVIĆ, „Ranokršćanski sarkofazi s otoka Brača“, in: Vjesnik za arheologiju i historiju dalmatinsku 75 (VAHD), Split, 1981., 105-135; V. KOVAČIĆ, „Topografija pojedinačnih nalaza”, in: Ranokršćanski spomenici otoka Brača, Split, 1994., 91, 94. Na trogirskom je sarkofagu linearna stilizacija reljefnog križa proširenih krakova s račvastim udubljenjem i središnjim diskom. Kasnoantički uzori sličnog tipa križa u medaljonu s naglašenim čvorom u obliku patere pronađeni su u crkvi sv. Kuzme i Damjana u Smrčeviku i kod crkve sv. Luke kraj Donjeg Humca. Križ s paterom bez vijenca nalazi se na salonitanskim Manastirinama i na supetarskom groblju. Usp. I. FISKOVIĆ, op. cit., 125 (n. 1); I. MATIJEVIĆ, „Anepigrafski sarkofazi in situ iz bazilike na Manastirinama“, in: Tusculum 4, Solin, 2011., 95, 100.

Tip figuralnog monumentalnog sarkofaga sa središnjim prikazom Dobrog pastira i bogatim narativnim scenama pronađen je na salonitanskim Manastirinama. Usp. N. CAMBI, „Krist i njegova simbolika u likovnoj umjetnosti starokršćanskog perioda u Dalmaciji“, in: VAHD LXX-LXXI, Split, 1968.-1969., 69-78; Idem, Sarkofag Dobroga pastira iz Salone i njegova grupa, Split, 1994. 
uočen motiv na trogirskim ranokršćanskim pilastrima. ${ }^{19}$ Iako je tip križa prilično rijedak u ranosrednjovjekovnoj skulpturi na području Srednje Dalmacije, nalazimo ga na srednjovjekovnom pilastru iz benediktinskog samostana sv. Marije de Taurello u Splitu. ${ }^{20}$ Kompozicija natpisnog polja sa središnjim križem u medaljonu i tekstom raspoređenom u četiri retka slična je onoj na nadvratniku crkve sv. Martina u sjevernom stražarskom hodniku Dioklecijanove palače. ${ }^{21}$

Trogirski je fragment pohranjen u depotu Muzeja grada Trogira (br. inv. 1206). Na gornjem rubu dijela sarkofaga (šir. $2,01 \mathrm{~m}$, vis. 0,57 m, deb. $0,10-0,13 \mathrm{~m}$ ) sačuvan je unutarnji zubac (šir. $4 \mathrm{~cm}$ ), dok je vanjski utor za nalijeganje poklopca dvostruko širi. Mehanička oštećenja na više su mjesta vidljiva uz vanjski brid otvora. Na bočnim stijenkama jasno su vidljivi tragovi pilenja i priklesavanja nastali prilikom uklapanja ploče u pločnik nad sarkofazima. Ipak je najviše uništen podanak s dijelom zadnjeg retka i posebno donja desna četvrtina završnog dijela natpisa. Posebno se ističe vrsna obrada lica primjenom antičke marteline kojom je pravilnim kosim potezima poravnata površina kamena, a na kojoj je srednjovjekovni klesar urezao pomoćne crte za natpis (sl. 4).

Ukop u sarkofagu mogla je dosegnuti samo ugledna osoba koja se isticala društvenim položajem ili plemenitim podrijetlom te zasigurno nije bila anonimna u svojoj sredini. Pretpostavljamo da neki od kasnijih sarkofaga, poput ovog ranoromaničkog s epitafom u kojem se pokojnik obraća Dobrom pastiru, nisu bili ukopani već vidljivi sa cijelim natpisom. Ipak, tragovi udaraca ukazuju na namjerno lomljenje sarkofaga i uništenje teksta, što se svakako odnosi i na njegov poklopac. Međutim, zadnja upotreba ovog natpisa i predromaničkog zabata nad sarkofazima u trijemu crkve sv. Marije svjedoči o naknadnom spašavanju spolija koji su posvećeno kamenje s tekstom molitve i zagovora. $\mathrm{Na}$ sarkofagu dominira devocionalni i soteriološki karakter epitafa, a prikaz je sveden isključivo na simbolizam znaka križa.

Križ u vijencu simbol je kršćanskog vjerovanja u Uskrsnuće, a ovaj trogirski prikaz je utemeljen na motivima i likovnoj tradiciji ranokršćanskih sarkofaga Srednje Dalmacije. Tekst započinje simboličkom invokacijom pod znakom križa, slijedi verbalno zazivanje Krista Dobrog pastira. Izjava ovis tua sum ima korijen u početku Davidova psalma: Gospodin je pastir moj / Dominus pascit me (Ps 22, 1). Na starozavjetnim tekstovima utemeljeno je i Ivanovo evanđelje u kojem je parabola o Isusu-Dobrom pastiru koji progovara: Ja sam pastir dobri, poznajem ovce svoje i ovce moje poznaju mene / ego sum pastor bonus et cognosco meas et cognoscunt me meae) (Iv 10, 14).

Ključna simbolika Isusa Dobrog pastira jest u tome da on svojim ovcama daje život vječni i čuva ih od propasti (Iv 10,27-28). Pravedan je prema svima, milosrdan prema izgubljenima i nemoćnima, brižan prema jakima (Ez 34, 16), a simboliku Dobrog pastira Ivan u svom evanđelju temelji na tekstovima starozavjetnih proroka.

Epitaf zadržava karakter molitvenog zagovora složen isključivo na kompilaciji biblijskih tekstova u kojima se pokojnik direktno obraća Kristu. Nema isticanja imena pokojnika niti kronoloških elemenata za dataciju pa možemo samo pretpostaviti da su takvi podaci bili upisani na poklopcu sarkofaga, kao i na poklopcu sa spomenom bizantskog cara Konstantina.

Predlažemo tekst prema sljedećem čitanju:

PASTVR BONE S[AN]C[T]IS[S]IME OVIS TVA S[VM]. RE/QVIRVM TE ET EGO SEMP[E] R VOLVI [COR]/PVS EVM E[V]M FAC[TVM] E[ST] ...../SVM[MV]M BON/V]M ET NON [PERIBUNT IN AETERNUM]

\footnotetext{
${ }^{19}$ V. KOVAČIĆ, „Prilozi za ranokršćansku topografiju Trogira“, in: Diadora 15, Zadar, 1993., 291-309.

20 Ž. RAPANIĆ, „Ranosrednjovjekovni latinski natpisi iz Splita“, in: VAHD LXV-LXVII, Split, 1963.-1965., 279-280.

${ }^{21}$ Ibidem, 288; V. DELONGA, Romanički natpisi grada Splita, Split, 1997., 13.
} 
Pastiru dobri presveti, Tvoja sam ovca;

tražim Tebe i uvijek sam želio tijelo troje postalo je....

najviše dobro i né́u [propasti zauvijek]

U tekstu epitafa pokojnik ispovijeda svoje kršćansko vjerovanje. Žudio je za tijelom Kristovim (Corpus Christi) koje dobiva u sakramentu Pričesti, te u zajedništvu s Bogom tijekom zemaljskog života doseže najviše dobro, iskazujući nadu u Uskrsnuće i život vječni. Summum bonum je za sv. Augustina sinonim za Boga koji je najviše dobro u središtu svijeta (De natura boni).

Jezik epitafa ubraja se u primjer vulgarnog latiniteta koji je prisutan i u drugim dalmatinskim gradskim sredinama. Tekst je isklesan u rustičnoj rimskoj kapitali s jednim uncijalnim slovom (q), a raspoređen je u četiri retka s obje strane kružnice s upisanim križem koji je središte natpisnog polja. U izboru pisma klesar je mogao koristiti predloške iz postojećih liturgijskih kodeksa koji su bili zbir znanja i izvori za epigrafske zapise, ali konačni rezultat pokazuje odlike improvizacije i nespretnosti. ${ }^{22}$ Dok su u prvom retku slova jasnog i stabilnog duktusa, u sljedećima gube proporciju, a gustoća i otklon od vertikalne osi stvaraju vizualni nesklad. Središte križa izmaknuto je ulijevo od sredine diska, što je neobično za znalački konstruiranu kružnicu. Pokušat ćemo analizom pojedinih znakova odrediti morfološke odlike i grafijsku stilizaciju natpisa (sl. 5).

Slovo A je izvedeno u uglatom obliku sa širokim gornjim dijelom i naglašenom gornjom ravnom crtom. Poprečna crta je slomljena, jednom izvedena kao stilizirani spoj dvaju lučnih dijelova koji se spušta gotovo do donjeg ruba retka. Slične tipove slova A susrećemo kod ranosrednjovjekovnih splitskih natpisa s konca 11. i početka 12. stoljeća, poput zabata iz crkve sv. Petra na Lučcu, na dijelu luka s posvetom sv. Mihovilu Arkanđelu, ulomaka arhitrava iz splitske katedrale i na nadbiskupskim sarkofazima. ${ }^{23}$

Slovo B pojavljuje se u dvije inačice. Sa širokim donjim pravilno zaobljenim lukom i užim gornjim, te uski tip slova s jedva naznačenim suženjem na sredini. U oba primjera lukovi se na sredini slova ne spajaju s hastom.

U prvom retku slovo C je oblo rastvorenih krajeva, a u drugoj varijanti u trećem retku je usko i uglato.

Slovo E ima samo jedan uski i uglati oblik sa širom srednjom crtom. Povezuje se sa samoglasnicima koji imaju naglašenu vertikalnu os poput $\mathrm{N}, \mathrm{Mi} \mathrm{T}$.

Slovo G izvedeno je u jednom potezu s jako izraženim završnim zavijutkom, a gornji kraj rastvoren je kao kod oblog C.

Iako je visina retka približno jednaka, velike su razlike u širini pojedinih slova, što je izrazito kod slova M koje se pojavljuje u raznim varijantama. Iznimno je široko s kosim linijama nožica i plitkim gornjim dijelom ili pak s lagano konveksnim nožicama i šiljcima u unutrašnjosti. Treba upozoriti na sličnost slova M s razmaknutim nožicama i kratkim gornjim dijelom s onim na nadvratniku crkve sv. Barbare u Trogiru ${ }^{24}$ i na epitafu splitskog nadbiskupa Lovre iz konca 11. stoljeća. ${ }^{25} \mathrm{Na}$ dočetku

\footnotetext{
22 Po sudu Viktora Novaka, dalmatinski srednjovjekovni epigrafski spomenici pokazuju opću povezanost natpisa s rukopisima. $\mathrm{Na}$ brojnim predromaničkim epigrafskim spomenicima s kapitalom se kombiniraju drugi grafijski sustavi poput uncijale i beneventane. Usp. V. NOVAK, Latinska paleografija, Beograd, 1987., 294.

U faksimilnom izdanju Splitskog evangelijara počeci evanđelja ispisani su u knjižnoj kapitali. Usp. Evangeliarium Spalatense, Književni krug (ed.), Split, 2004.

Vjerujemo da su u Trogiru u skriptoriju benediktinskog samostana sv. Ivana Krstitelja prepisivani slični kodeksi, a stilizacija grafema postaje uzor za klesarsko oblikovanje natpisa. Iako su integralno sačuvani tek kodeksi 13. stoljeća (Trogirski evanđelistar), isječci ranih rukopisa, ulijepljeni u podstavu kasnijih liturgijskih knjiga, upućuju na dodatno razmatranje ove teme.

23 Ž. RAPANIĆ, op. cit., 273-276, 297-306 (n. 20); V. DELONGA, op. cit., 8-9, 22-23, 26-27 (n. 21).

${ }^{24}$ R. BUŽANČIĆ, „Predromanička pregradnja crkve sv. Martina u Trogiru“, in: PPUD 35, Split, 1995., 241-251.

25 Ž. RAPANIĆ, op. cit., 304-306 (n. 20); V. DELONGA, op. cit., 22-23 (n. 21).
} 


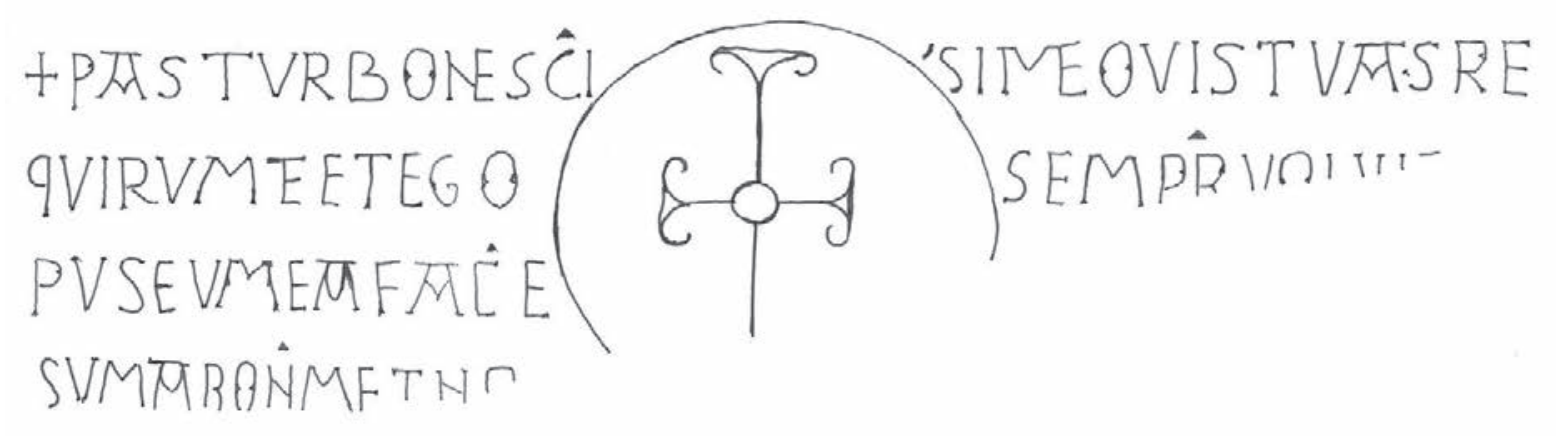

Sl. 5. Crtež natpisa epitafa

Fig. 5. Drawing of the inscription of the epitaph

glagola requirum je slovo M s prebačenom gornjom crtom koja prelazi preko lijeve strane. Slična stilizacija je korištena na naličju kamene grede s natpisom klesara Dominika iz Splita. ${ }^{26}$ Jedino u prvom retku, kada je spojeno sa samoglasnikom E, slovo M se pojavljuje s uspravnim nožicama, ali doseže dvostruku širinu i prelazi maksimalne proporcije pojedinih slova natpisa.

Za slovo N klesar koristi isti uspravni oblik sa spuštenom kosom crtom koje varira u širini.

Slovo $O$ je oblo s manjim deformacijama, a na sredini s unutrašnje strane ima dva ukrasna šiljka. Taj ukrasni element dosegao je izvrsna ostvarenja u splitskoj i trogirskoj ranoromaničkoj epigrafici u obliku bušene točke ili zrna (perlatura). ${ }^{27}$

Na početku teksta u invokaciji Dobrom pastiru kod slova P u riječi Pastur hasta je dublje spuštena ispod donje crte retka poput inicijala. Isto slovo se pojavljuje sa spuštenim lučnim dijelom i urezanim trokutićem na strelici luka.

Samo slovo $Q$ preuzeto je iz uncijalnog pisma i formirano sa zatvorenom ušicom i spuštenom nožicom.

Slovo R izvedeno je s ravnom i izvijenom nožicom, a lučni dio varira do gotovo poligonalnog s ravnom gornjom crtom i urezanim trokutićem na sredini luka.

Klesar je prema nekom ranoromaničkom uzoru unutrašnju stranu lučnih dijelova slova naglasio točkama odnosno trokutićima (O, P, R, M). Najbliži uzori su svakako splitski natpisi 11. stoljeća na fragmentima greda ranoromaničke oltarne pregrade splitske katedrale, nadvratniku u crkvi sv. Julijane i oltarnoj pregradi iz crkve sv. Martina. ${ }^{28} \mathrm{U}$ širem jadranskom kontekstu na apulskim ranoromaničkim posvetnim natpisima na sličan su način naglašena slova. ${ }^{29}$

Kod slova S su dvije varijante: s višim i rastvorenim gornjim polukrugom, ili s kraćom gornjom polovicom koja ima gotovo ravan početak.

Slova T i V su vrlo pravilnog oblika bez osobitih detalja.

Natpis obiluje rustično izvedenim znakovima, a vidljive su razlike u visini, kao i nejednakost u razmacima između slova. Često se u drugoj polovici retka i u donjim dijelovima epitafa usitnjava tekst i koristi više skraćenica.

\footnotetext{
26 Ž. RAPANIĆ, op. cit., str. 289 (n. 20).

${ }^{27}$ V. DELONGA, „Ranoromanički natpisi u latinskoj epigrafici kraljevske Hrvatske“, in: Arheološka istraživanja u Kninu i Kninskoj krajini, Znanstveni skup Knin, 13-15. X. 1987., Izdanja Hrvatskog arheološkog društva, sv. 15, B. ČEČUK (ed.), Zagreb, 1992., 90-92.

28 Ž. RAPANIĆ, op. cit., 273 (n. 20); V. DELONGA, op. cit., 13, 17 (n. 21).

${ }^{29}$ Fragmenti oltarnih pregrada u svetištu sv. Mihovila u Montesantangelu i katedrali u Sipontu, datirani oko polovice 11. stoljeća, elegantni su primjeri takve stilizacije. Usp. P. BELLI D'ELIA, Alle sorgenti del romanico - Puglia XI secolo, Bari, 1987., 41, 60.
} 
Uz Dobrog pastira je pridjev presveti (sanctissime). To je primjer nomina sacra koji je u epigrafskoj kontrakciji S(an)CT)IS(s)IME. Umjesto crtice iznad kontrakcije klesar koristi točku koju kosim rezom oblikuje u trokut. Također ubacuje dijakritički znak (sicilicus) pred slovom S kako bi označio dvostruki samoglasnik.

U drugom retku iznad slova $\mathrm{P}$ i R je skraćenica u obliku trokuta za -per, na kraju riječi semp (e)r. Također u zadnjem retku iznad slova $\mathrm{N}$ i M je skraćenica za samoglasnik U kod riječi bon(u)m. Crtica iznad slova M na kraju riječi označava završetak -um u riječi sum(u)m. Na kraju prvog retka je točka uz siglu ispred slova.S sa značenjem sum.

Kakvim se uzorima mogao koristiti nepoznati trogirski klesar pri izradi ovog epitafa?

Sastavljač teksta je, po svoj prilici klerik, predložio strukturu i stil epitafa, a možda i predložak oblika pisma kao uputu klesaru za izvedbu i prilagodbu natpisnom polju. Međutim, klesar je zasigurno unio elemente govornog jezika, paleografske i lingvističke pogreške, pa već u drugom retku imamo oblik requirum te umjesto requiram te. Uz imenicu (cor)pus, koja je srednjeg roda, prisvojna je zamjenica u akuzativu jednine muškog roda eum. Dva puta je uklesana zamjenica eum, iako se po načinu govora pokojnik obraća neposredno Kristu. EVM je prvi put izvedena jasnim grafijskim znakovima, a zatim skraćena izradom ravne gornje crte iznad slova $M$ kao i u zadnjem retku. Na isti način je nepažnjom klesara na nadvratniku crkve sv. Julijane u Splitu dva puta urezan slog ED (ededificavi). ${ }^{30}$

Dočetak imenice pastor na -ur (pastur) fonetska je pojava karakteristična za stariji dalmatinski vulgarni latinitet kada se klasično lat. - o zamjenjuje vulgarnim lat. $-u .{ }^{31}$ Istaknuti primjer kasnoantičkog epitafa pripada salonitanskom svećeniku Ivanu koji se spominje kao peccatur et indignus presbiter, a datiran je koncem 6. ili početkom 7. stoljeća. ${ }^{32}$ Stari oblici provincijskog latiniteta dugo se održavaju u govornom jeziku i susrećemo ih na epigrafskim spomenicima s konca 8. i početka 9. stoljeća u Zadru i 10. stoljeća u Trogiru. Tako se isti oblik peccatur pojavljuje na kovčežiću sv. Stošije u Zadru (Peccatur Donatus Episcopus), ${ }^{33}$ na gredama biskupa Donata iz zadarske katedrale (Donatus peccatur episcopus fecit), ${ }^{34}$ sarkofagu iz Zadra (Georgius peccatur presbiter et reclausus) ${ }^{35}$ i na luku oltarne pregrade iz Trogira (...ego procon[sul]... peccatur una cum coniuge me [a...]. ${ }^{36}$

Oblik pastur iz latinskog provincijalnog govora u suglasju s riječima requirum i eum unosi posebnu zvučnost ponavljanih samoglasnika na razmatranom trogirskom epitafu.

Epitaf s ranoromaničkog sarkofaga pokazuje skromnu razinu podučenosti u latinskoj pismenosti i kulturi u Trogiru čiji je nosilac svakako bio muški benediktinski samostan sv. Ivana Krstitelja. Za razliku od teksta sarkofaga splitskog i zadarskog visokog klera kao i Petra Crnog, koji se ubrajaju u iznimna ostvarenja latinskog pjesništva, trogirski epitaf je izvedenica nastala citiranjem psalama i molitvi, vjerojatno iz pera nekog klerika. Liturgijske je rukopisne tekstove preradio u rustičnu kapitalu koja je bila prikladnija klesanju epitafa.

Već nakon smrti trogirskog biskupa Ivana 1111. godine, nepoznati je pisac sastavio Život sv. Ivana Trogirskog koji je nadopunio trogirski arhiđakon i kasniji biskup Treguan 1203. godine. Tu je done-

30 Ž. RAPANIĆ, op. cit., 278 (n. 20); V. DELONGA, op. cit., 16-17 (n. 21).

${ }^{31}$ P. SKOK, „Pojave vulgarnog latinskog jezika na natpisima rimske provincije Dalmacije“, in: Djela JAZU 25, Zagreb, 1915., 15, 32; Idem, „Iura Sancti Petri de Gomai“, Supetarski kartular, Zagreb, 1952., 241.

${ }^{32}$ Salona IV, Inscriptions de Salone Chrétienne IVe-VIIe siècles, I, Collection de l'Ecole francais de Rome 194/4; E. MARIN (éd.), Rome-Split, 2010., no. 96 (N. Gauthier).

${ }^{33}$ I. PETRICIOLI, „Ranosrednjovjekovni natpisi iz Zadra“, in: Diadora 2, Zadar, 1962., 253.

${ }^{34}$ P. VEŽIĆ, „Prezbiterij katedrale u Zadru“, in: PPUD 30, Split, 1990., 56, 59, 62; Hrvati i Karolinzi: katalog izložbe, 2, Muzej hrvatskih arheoloških spomenika, Split, 20. prosinca 2000.-31. svibnja 2001., A. MILOŠEVIĆ (ed.), Split, 2000., III. 41.

${ }^{35}$ J. VUČIĆ, „Georgius peccatur presbiter et reclausus", in: Vjesnik za arheologiju i povijest dalmatinsku 106 (VAPD), Split, 2013., 241.

${ }^{36}$ T. BURIĆ, op. cit., 146, 154, 156 (n. 10); Idem, „Tko je bio prokonzul trogirskog zabata?“, in: SHP 20, Split, 1990., 239-249. 
sena Ivanova molitva na času smrti u kojoj iskazuje brigu za one kojima je bio pastor animarum „... Preporučam tebi, dobri pastiru, stado koje si ti, dok sam bio živ, povjerio mojoj brizi. Ponizno molim tvoje veličanstvo za njih da ih i sada suobraziš svojoj milosti te da u budućnosti budu sudionici tvoje slave, Spasitelju i Otkupitelju svijeta, u čije ruke polažem duh svoj. " 37

Između ovog teksta i epitafa s trogirskog sarkofaga svakako postoji sadržajna i kronološka povezanost. Oba se u molitvi obraćaju Dobrom pastiru, jedan kao zemaljski pastir i dušebrižnik, a drugi kao pripadnik njegova stada. U Životu sv. Ivana navodi se da je svečev grob 1123. godine oskvrnut u saracenskoj pljački i rušenju grada koji su poduzeti po nalogu Normana iz Barija, ${ }^{38}$ zapušten i gotovo zaboravljen sve do njegova čudesnog našašća nakon više desetljeća. ${ }^{39}$ Polovicom 12 . stoljeća izrađen je prvi kameni sarkofag u kojem su pohranjeni zemni ostaci trogirskog biskupa Ivana te je postavljen uz oltar sv. Kuzme i Damjana u katedrali sv. Lovre. Položaj groba, po uzoru na grobove ad sanctos u bazilikama posvećenima mučenicima, naknadno je obilježen s južne strane glavnog oltara, u neposrednoj blizini podzemne konfesije s nišom za relikvije titulara katedrale. ${ }^{40}$ Prema pogrebnom običaju, visoki kler se pokapao u svetištu blizu relikvija mučenika, a neki od njih, zahvaljujući čudima i ozdravljenjima bolesnika, i sami dolaze na glas svetosti i postaju predmet kulta poput sv. Ivana Trogirskog.

Između teških kušnji i stradanja koje je Trogir proživljavao tijekom 12. stoljeća, poduzeti su mukotrpni radovi na obnovi grada. Stoga ranoromanički epitaf na reutiliziranom ranokršćanskom sarkofagu možemo dovesti u vezu s vijestima o dostojnom pokapanju trogirskog božanskog zaštitnika. Njegov je počinak ponovno narušen 1171. godine kada Mlečani razbijaju sarkofag, oskvrnjuju pokojnikovo tijelo i otimaju njegovu ruku. Sarkofag sv. Ivana nosio je svečevo tijelo tek dva desetljeća, ali je uklesani tekst molitve kao Ivanov credo ostao sačuvan. Zasigurno je epitaf sa zagovorom Dobrom pastiru bio otrgnut zaboravu te je, zajedno sa zabatom na kojem je formula zagovora Bogorodici, zakrilio kasnije ukope u predvorju crkve sv. Marije.

37 Život svetoga Ivana Trogirskoga: Legende i kronike, M. IVANIŠEVIĆ (ed.), Split, 1977., 61-62, 77, 111; P. LUCIĆ, Vartal, N. KOLUMBIĆ (ed.), Split, 1990., 106; I. LUCIĆ, Život sv. Ivana Trogirskog, po izdanju Daniela Farlatija, K. LUČIN (trans.), Trogir - Split,1998., 68-69; D. FARLATI, Trogirski biskupi, K. LUČIN (trans.), J. NERALIĆ (ed.), Split, 2010., 89-90.

U latinskom izvorniku tekst glasi: Recommendo tibi, pastor bone, gregem, quem mea solicitudini, dum viverem, commendasti. Majestatem tuam pro illis supliciter exorans, ut eos et in praesenti tua conformes gratia, et in futuro tuae gloriae attribuas esse participes, Salvator et Redemptor mundi, in ejus manus commendo spiritum meum.

${ }^{38}$ L. MARGETIĆ, „La distruzione di Traù da parte dei Saraceni nella prima metà del secolo XII“, in: Histrica et Adriatica 2, Rovigno,1983., 255-263.

${ }^{39}$ M. IVANIŠEVIĆ, op. cit., 965 (n. 11).

${ }^{40}$ R. BUŽANČIĆ, „Secundum sacrarium divi Ioannis. Stara kapela sv. Ivana Trogirskog u katedrali sv. Lovrinca“, in: PPUD 40, Split, 2003.-2004., 77-112; V. KOVAČIĆ, „The Gradus Descensionis in the Presbitery of St Lawrence's Cathedral in Trogir", in: Hortus Artium Medievalium 15/1, Zagreb-Motovun, 2009., 71-72; J. NERALIĆ, „Biskup Ivan Trogirski (1064.-1111.) osnivač benediktinskog samostana sv. Nikole", in: Benediktinski samostan sv. Nikole u Trogiru. Duhovnost i kultura u okrilju Virgines Dei. Zbornik radova prigodom 950. obljetnice utemeljenja, V. KOVAČIĆ, J. MILANOVIĆ (ed.), Trogir, prosinac 2014., 94-100.

Relikviju rebra sv. Lovre spominje P. Andreis u svom rukopisu o trogirskim crkvama. Usp. D. ZELIĆ, „Chiese in Traù - rukopis P. Andreisa u Muzeju grada Trogira“, in: Radovi Instituta za povijest umjetnosti 33, Zagreb, 2009., 94, 103. 


\section{EPITAPH WITH A PRAYER OF INTERCESSION TO THE GOOD SHEPHERD}

\section{Proposal for the sarcophagus of John, Bishop of Trogir}

During works being carried out in the interior of the Church of St Sebastian in the main city square in Trogir, the discovery was made of walls of the former portico of the hexafoil Church of St Mary, demolished in the $19^{\text {th }}$ century. Under the paving of the forecourt of St Mary's three sarcophagi with lids were buried. They were ancient stone sarcophagi that had been reutilised in the Early Middle Ages. On some, the reliefs had been deleted and new lids been made. All of the sarcophagi were used in the $13^{\text {th }}$ and $14^{\text {th }}$ century, as shown by the finds of Venetian piccoli and spalatini.

A sarcophagus found earlier in the centre of St Mary's Church indicated that this hexafoil church had a sepulchral and memorial importance. The early medieval sarcophagi, privileged burials under the paving of the portico, confirm the outstanding respect accorded the central grave. After the secondary burials in sarcophagi in the paving, the gable of the altar screen of the $9^{\text {th }}$ century and part of a Romanesque sarcophagus on which there were inscriptions from prayers of intercession to the Virgin and to Christ the Good Shepherd were used as spolia. The slab with the epitaph is a medieval reinterpretation of the Early Christian crux coronata motif, a symbol of the Resurrection. The sarcophagus has a devotional and soteriological character, and the depiction is reduced to the symbolism of the sign of the cross. The address of the decedent to the Good Shepherd, Christ, has the character of a prayer of intercession composed entirely on a compilation from Old Testament Psalms (Ps 22:1) and the Gospel according to St John (John 10:14, 27-28).

The language of the epitaph can be classified as an example of vulgar Dalmatian Latinity, and it is carved in rustic Roman capitals, with a single uncial letter (q). The inscription abounds in rustically made signs as well as awkward expressions, and we believe that it brought in elements of the vernacular, as well as palaeographic and linguistic errors.

Immediately after the death of John, Bishop of Trogir, an anonymous author wrote the "Life of St John of Trogir", which was supplemented by archdeacon and later bishop of Trogir, Treguan, in 1203. This contains John's prayer at the hour of his death in which he commends his flock to the Good Shepherd, evincing thus his concern for those to whom he was pastor animarum. There is certainly a connection in content and chronology between this text and the epitaph of the Trogir sarcophagus. In the prayer, both look to the Good Shepherd, one as earthly pastor and confessor, and the other as member of his flock. The "Life of St John" says that in 1123 the saint's grave was desecrated during the Saracen sacking and pillaging of the city, carried out on the orders of the Normans of Bari. It was then neglected and almost forgotten until it was miraculously found several decades later. In the middle of the $12^{\text {th }}$ century the first stone sarcophagus was made, and in it were put the mortal remains of Bishop John of Trogir. Together, they were placed alongside the Altar of SS. Cosmas and Damian in the Cathedral of St Lawrence. According to the interment customs of the time, senior clergy were buried in the chancel close to the relics of the martyr, and some of them, thanks to the miracles and the cures of the sick reported, themselves attracted the reputation of sanctity and became the subject of a cult, like that of St John of Trogir.

Hence the Early Romanesque epitaph on the reutilised Early Christian sarcophagus can be connected with the information about the dignified burial of the heavenly patron of Trogir. His repose was interrupted once again in 1171 when the Venetians smashed the sarcophagus, desecrated the body of the deceased, and stole his arm. The Sarcophagus of St John actually held his body for only two decades. Yet the carved text of the prayer, John's credo, was preserved, and taken from the cathedral to the forecourt of St Mary's church.

Key words: Trogir, crkva sv. Marije, šesterolist, crkva sv. Sebastijana, predvorje, sarkofag, epitaph, sv. Ivan Trogirski

Translation: Graham McMaster 